\title{
Bacterial activity during early winter mixing (Gulf of St. Lawrence, Canada)
}

\author{
Connie Lovejoy ${ }^{1, *}$, Louis Legendre ${ }^{1}$, Bert Klein ${ }^{1}$, Jean-Éric Tremblay ${ }^{1}$, \\ R. Grant Ingram ${ }^{2}$, Jean-Claude Therriault ${ }^{3}$
}

\author{
${ }^{1}$ Département de biologie, Université Laval, Québec, Québec, Canada G1K 7P4 \\ ${ }^{2}$ Department of Atmospheric and Oceanic Sciences, McGill University, 805, Sherbrooke Ouest, Montreal, Québec, \\ Canada H3A $2 \mathrm{~K} 6$
}

${ }^{3}$ Maurice-Lamontagne Institute, Department of Fisheries and Oceans, PO Box 1000, Mont-Joli, Québec, Canada G5H 3Z4

\begin{abstract}
Bacterial dynamics were examined in early winter in the Gulf of St. Lawrence (Canada) at a time of rapid changes in water column properties. At all stations, bacterial production as measured by [methyl- $\left.{ }^{3} \mathrm{H}\right]$-thymidine $\left({ }^{3} \mathrm{H}\right.$-TdR) was significantly correlated with chl $a$ and with the number of Actively Respiring Cells (ARCs). ARCs were defined as metabolically active bacteria which reduced the tetrazolium salt 5-cyano-2,3-ditolyl tetrazolium chloride (CTC) to red fluorescent, water-insoluble formazan crystals that were detected by epifluorescence microscopy. There was little change in the total bacterial concentrations determined with DAPI (4',6-diamidino-2-phenylindole) and no significant correlation between the thymidine production values and DAPI counts. ARCs represented ca 1 to $2 \%$ of total bacterial cell counts in the surface mixed layer when the water column was stratified, falling to less than $0.1 \%$ when there was deep mixing. These observations suggest that only a small fraction of the total bacterial biomass is metabolically active at any one time. These findings support the view that the relatively constant total bacterial cell concentrations in the sea are determined by loss rather than growth processes.
\end{abstract}

KEY WORDS: Bacteria CTC D DAPI Thymidine uptake Microbial food webs

\section{INTRODUCTION}

Bacterial production associated with the phytoplankton spring bloom has been the subject of numerous studies (e.g. Ducklow \& Kirchman 1983, Simon \& Tilzer 1987, Martin-Jézéquel \& Videau 1992, Ducklow et al. 1993) and much data exist on mid-latitude annual and high-latitude summer conditions (e.g. Fuhrman \& Azam 1980, Fuhrman et al. 1989, Azam et al. 1992, Kirchman et al. 1993). In contrast, there is a paucity of information about bacterial production and biomass changes during periods of rapid destabilization of the water column in late autumn-winter. At that time of the year, decreased solar irradiance and increased depth of mixing reduce the average light which is available to phytoplankton. Photosynthetic activity on an areal

•E-mail: c595@music.ulaval.ca basis declines but nutrients are entrained into the euphotic zone and may lead to a brief autumn bloom. However, seasonal changes in the activity of heterotrophic bacteria do not necessarily follow those of phytoplankton, but whether the two are actually coupled remains mostly unknown.

The present study was conducted in early winter using a combination of approaches to measure bacterial dynamics, i.e. ${ }^{3} \mathrm{H}$-thymidine $\left({ }^{3} \mathrm{H}\right.$-TdR) uptake to estimate production rates, bacterial cell concentrations to estimate biomass changes, and a fluorescence assay of Actively Respiring Cells (ARCs) as a further guide to metabolic changes in the bacterial population. We also measured a number of other biological and oceanographic variables.

During periods of stratification, bacteria from deeper waters typically show much lower uptake of ${ }^{3} \mathrm{H}$-TdR than surface populations (Banse 1992, Ducklow et al. 
1992). We hypothesized that the relationship between bacterial productivity and biomass would be substantially weakened during early winter destratification, when bacteria are mixed from depths well below the zone of active photosynthesis and DOC (dissolved organic carbon) production. This period of decoupling between bacterial biomass and productivity would be characterized by a change in the percentage of ARCs.

We compared ARCs over time and space using the fluorescent redox probe CTC (5-cyano-2,3-ditolyl tetrazolium chloride). There are at present a multitude of tetrazolium salts used to study redox reactions of both in situ and in vitro cell suspensions (Moore 1985 and references therein). The tetrazolium salt CTC yields fluorescent formazan crystals when in a reduced state. CTC was developed and initially applied to measure respiration in Ehrlich ascites tumor cells (Stellmach 1984, Stellmach \& Severin 1987). This redox probe is related to 2 ( $p$-iosophenyl)-3-( $p$-nitrophcnyl)5 -phenyl tetrazolium chloride (INT) which has been widely used to detect actively respiring bacteria (e.g. Zimmermann et al. 1978, Tabor \& Neihof 1984, Byrd \& Colwell 1993). Rodriguez et al. (1992) applied the CTC assay under laboratory conditions, using Pseudomonas putida and natural samples which included sewage, groundwater and seawater obtained from the pier at Newport Bay, CA, USA. Kaprelyants \& Kell (1993a) used CTC in combination with flow cytometry to measure the respiratory activity as well as dormancy (Kaprelyants \& Kell 1993b) of Micrococcus luteus cells grown in a chemostat. There has been little previous work to develop the CTC assay for application in the field (McFeters et al. 1995). Such a development was among the aims of the present study.

The Gulf of St. Lawrence, Canada, is an area where plankton communities are floristically diverse, and contains autotrophic picophytoplankton as well as small bacterioplankton. The Gulf is characterized by a wide range of hydrodynamic conditions (Therriault 1991), so that different production and biomass variables can be examined over a relatively short period in different types of marine systems. This made the Gulf an ideal site for examining bacterial responses to the rapid changes which characterize the north temperate occan during early winter

\section{MATERIALS AND METHODS}

Field studies. Samples were collected in the Gulf of St. Lawrence at sites which were chosen because of their different hydrodynamic characteristics (Fig. 1). Measurements were taken from 3 contrasting areas in the Gulf during early winter, when the surface mixed layer was cooling and deepening; the 3 sites (Stns 4, 5

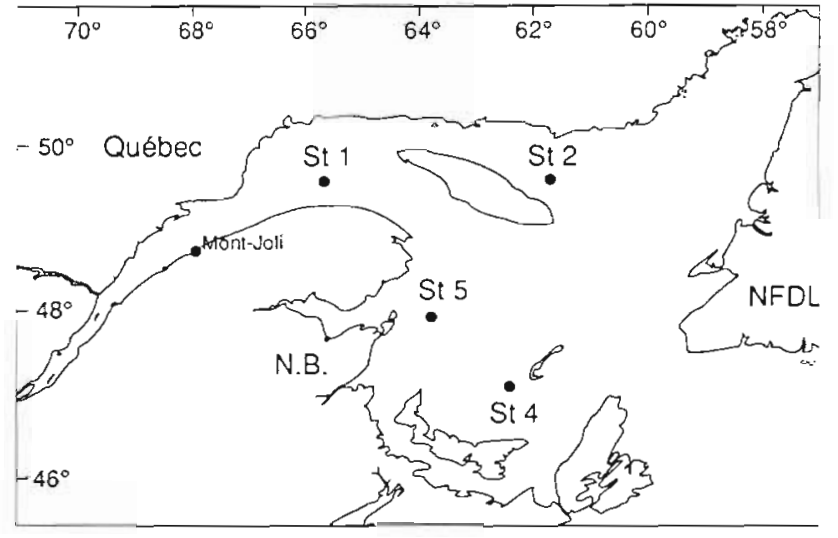

Fig. 1. Location of the 4 sampling stations in the study area: Stn 4, Iles-de-la-Madeleine, $47^{\circ} 05^{\prime} \mathrm{N}, 62^{\circ} 30^{\prime} \mathrm{W}$, maximum depth $\left(z_{\max }\right)$ ca $60 \mathrm{~m}$; Stn 5 , La Mèque Island, $47^{\circ} 48^{\prime} \mathrm{N}, 64^{\circ}$ $00^{\prime} \mathrm{W}, z_{\max } \mathrm{ca} 80 \mathrm{~m}$ i Stn 1, Anticosti Gyre, $49^{\circ} 40^{\prime} \mathrm{N}, 66^{\circ} 00^{\prime} \mathrm{W}$, $z_{\text {max }}$ ca $355 \mathrm{~m}$. These 3 stations were sampled in late November and early December 1993. Experiments were conducted April 1994 at Stn 4 and Stn 2, Detroit de Jacques Cartier, $42^{\circ} 40^{\prime} \mathrm{N}, 62^{\circ} 00^{\prime} \mathrm{W}, z_{\max }$ ca $275 \mathrm{~m}$

and 1) were visited on board the CSS 'Parizeau' during the last week of November and first week of December 1993. In April 1994, 2 additional experiments were conducted to verify the earlier methodology, one at Stn 4, and the other at Stn 2. Sampling was from the Canadian Coast Guard icebreaker 'Sir Wilfrid Laurier'. Vertical profiles of temperature, salinity, in vivo fluorescence (Sea Tech ${ }^{\circledR}$ Fluorometer) and photosynthetically available radiation (PAR; BioSpherical Instruments SPQ 200) were recorded with a Seabird SBE 25 CTD mounted on a rosette sampler (General Oceanics) or a Seabird SBE 19 CTD. Samples were collected on the upcasts with 81 lever-action Niskin bottles (General Oceanics). All samples for microbial analyses were prefiltered through a cleaned $200 \mu \mathrm{m}$ Nitex filter and collected into 1 l Nalgene bottles which had been cleaned, acid rinsed and rinsed 3 times with sample water prior to filling These were stored in the dark at approximately $2^{\circ} \mathrm{C}$, and all subsequent analyses were done on subsamples from these bottles.

Sample analyses. Samples for bacterial cell counts were preserved with $1 \%$ (final concentration) $0.22 \mu \mathrm{m}$ prefiltered formaldehyde. These samples were stored in the dark and cold ( 2 to $4^{\circ} \mathrm{C}$ ) until subsequent filtration and stained with $1.8 \times 10^{-3} \mathrm{mg} \mathrm{m}^{-1}$ final concentration of DAPI (Hobbie et al. 1977, Porter \& Feig 1980). Cells were counted at $1000 \times$ using either a Leitz Dialux 22 fluorescence microscope (100x Leitz Pl Fluortar objective and Leitz filter block $\mathrm{A}$, excitation 340 to $380 \mathrm{~nm}$ ) or Zeiss Axiovert 100 fluorescent microscope (100× Plan-Neofluar objective filter block 02, excitation $365 \mathrm{~nm}$ ); 400 to 800 cells were counted on each filter. All filtrations were carried out within 1 mo, and 
subsequent counts were carried out within 2 mo of collection. Differences between replicate samples filtered and counted $1 \mathrm{wk}$ after collection and those filtered, stored frozen and counted at the end of 2 mo were not statistically significant. However, since samples were not filtered at sea immediately after collection we cannot discount the possibility of some cell loss during storage, hence total bacterial numbers may be slightly underestimated (see Turley \& Hughes 1992).

Samples for prokaryotic and eukaryotic picophytoplankton were filtered in the field within $3 \mathrm{~h}$ of collection, and DNA stain Hoechst $33342\left(18 \times 10^{-3} \mathrm{mg} \mathrm{m}^{-1}\right.$ final conc.) was added. The samples were filtered onto $25 \mathrm{~mm} 0.22 \mu \mathrm{m}$ pore size black Nuclepore ${ }^{\oplus}$ filters. The resulting slides were frozen immediately and counted within $6 \mathrm{wk}$. The picophytoplankton were counted using a Zeiss Axiovert 100 fluorescence microscope at $1000 \times$ magnification (100x Plan-Neofluar objective) To count phycoerythrin- or phycocyanin-containing cyanobacteria, Zeiss filter block combinations 15 (green BP, 546/12 excitation) and 09 (blue BP, 450 to 490 excitation) were used. To count small eukaryotes containing chl a, blocks 09 and 05 (violet BP, 400 to 440 excitation and wide-band transmittance) were used. A total of 100 to 400 cells were counted on each filter.

A working solution of CTC (Polysciences, Warrington, PA, USA) was made up by dissolving $8.3 \mathrm{mg} \mathrm{m}^{-1}$ in sterile $0.2 \mu \mathrm{m}$ filtered deionized water, and then refiltering through a $0.2 \mu \mathrm{m}$ filter. This solution was stored in the dark at $2^{\circ} \mathrm{C}$ until use. While working with CTC, we observed that, on exposure to UV and violet light, the chemical is photoreduced and crystals of formazan are formed which resemble the labeled bacterial cells. All work with this chemical was subsequently conducted either in the dark or under dimly lit conditions, and all samples during all stages of analysis were guarded from light which may have contained wavelengths <420 nm (cf. Van Noorden \& Tas 1982). Water samples for CTC labeling were dispensed within $2 \mathrm{~h}$ of collection into either acid cleaned and sample rinsed $7 \mathrm{ml}$ plastic or $20 \mathrm{ml}$ glass scintillation vials or sterile glass $8 \mathrm{ml}$ vacutainers. Except for the experiments which specifically measured the uptake of CTC at varying concentrations, the CTC was added to the samples to obtain a final concentration of $0.75 \mathrm{mM}$. After dispensing and inoculating the vials, these were placed in a plastic bag, double wrapped in aluminum foil and incubated at the temperature of the surface mixed layer in an on-deck incubator. The samples were incubated for $2 \mathrm{~h}$ (except where noted) and then killed with $1 \%$ (final volume) $0.22 \mu \mathrm{m}$ filtered formaldehyde before storing in the dark at $2^{\circ} \mathrm{C}$ until analysis.

The concentration of CTC which we used for the uptake experiments $(0.75 \mathrm{mM})$ is much lower than the
2 to $5 \mathrm{mM}$ suggested by Rodriguez et al. (1992) or Kaprelyants \& Kell (1993a), but similar to that originally used by Stellmach (1984). Initial incubations using higher concentrations were characterized by a lack of repeatability and high background fluorescence. In April 1993 the effect of various CTC concentrations was investigated. Replicates at the lower concentration used in the field were within $10 \%$, with clear differences between stations and depth.

The CTC-labeled samples were filtered $<100 \mathrm{~mm}$ $\mathrm{Hg}$ ) onto $25 \mathrm{~mm}, 0.2 \mu \mathrm{m}$ pore size Whatman ${ }^{\otimes}$ Anodisc inorganic membrane filters with a $0.45 \mu \mathrm{m}$ pore size cellulose nitrate membrane backing filter, using a glass frit Millipore base. The Anodisc filter was mounted on a glass slide under a coverslip, using Polysciences water-soluble Aquapolymount ${ }^{\circledR}$. Anodisc filters have the advantage of being ridged and flat, which minimizes the risk of having poorly defined areas on the filter resulting in underestimation of total cell numbers. The water-soluble mounting medium resulted in more stable formazan crystals than samples mounted using immersion oil which appeared to dissolve the crystals (see also King \& Parker 1988). The prepared slides were either counted immediately or stored frozen for 1 to $30 \mathrm{~d}$. Samples were examined microscopically for CTC-fluorescent formazan crystal formation, and we were able to enumerate ARCs in the bacterial size range. Between 100 and 600 cells per filter were counted, except in samples with extremely low activity, in which 200 fields were counted. Cells were counted at $630 \times($ Plan-Neofluar objective $63 \times$ ) or $1000 \times$ (Plan-Neofluar objective 100×) using a Zeiss Axiovert 100 microscope and filter blocks 09 and 15 . The 2 blocks were used to distinguish the CTC-labeled bacteria, which are characterized by their small size and distinct red fluorescent color, from phycoerythrinand phycocyanin-containing cells. The fluorescence of cyanobacterial pigments changes markedly with changing illumination, but CTC-red fluorescence does not. The chl a containing cells are not as bright and fade quickly compared with CTC-formazan crystals. The only other fluorescent component in the size range of interest present in the samples was small cryptophytes, which are orange, much larger and distinctly reniform. With practice and after verifying the type of community in each sample, the 09 (blue) block proved sufficient for routine counting. In addition to the problem of photoreduction previously mentioned, unreacted CTC fluoresces in the UV range, which unfortunately precludes the double staining with DAPI suggested by Rodriguez et al. (1992).

Bacterial production was measured using the ${ }^{3} \mathrm{H}$ thymidine protocol outlined for oligotrophic waters by Robarts \& Zohary (1993). Within $1 \mathrm{~h}$ of collection, 30 to $60 \mathrm{ml}$ samples of water were placed into Whirlpak bags 
or $60 \mathrm{ml}$ culture flasks, ${ }^{3} \mathrm{H}-\mathrm{TdR}$ (Dupont NEN) with a specific activity of approximately $81 \mathrm{Ci} \mathrm{mmol}^{-1}$ (concentration $1 \mathrm{mCi} \mathrm{ml}^{-1}$ ) was added directly (final concentration $20 \mathrm{nmol} \mathrm{TdR}^{-1}$ ). Samples were incubated in the same on-deck incubator used for the CTC samples. As was done for CTC, the bags were shielded from light using aluminum foil. At the end of $2 \mathrm{~h}, 1 \mathrm{ml}$ of $5 \mathrm{~N}$ $\mathrm{NaOH}$ per $10 \mathrm{ml}$ of sample was added to stop the uptake. In our experiments with field samples, TdR uptake has always been linear in incubations up to $6 \mathrm{~h}$ (data not shown). The samples were stored frozen until DNA could be extracted and the incorporated radioactivity measured. This was done within 3 mo of collection, previous tests having shown no loss of activity under these circumstances (data not shown). One control sample from each depth was killed with $\mathrm{NaOH}$ immediately after the ${ }^{3} \mathrm{H}-\mathrm{TdR}$ was added, and frozen. Uptake was calculated using the average DPM of 2 or 3 replicates minus this control. Radioactivity was measured using a LKB Wallac Rackbeta scintillation counter. Efficiency and quenching were evaluated with internal standards, and independently with external standards.

Samples for chl a were collected at the same time as the microbial samples. After filtering onto GF/F filters immediately upon collection and extracting overnight with $90 \%$ acetone, fluorescence was measured using a Turner 111 fluorometer. Chl a concentrations were calculated following Holm-Hansen et al. (1965).

Primary productivity was determined using water collected in conjunction with the microbial and chl a samples. The daily rate of photosynthesis was obtained over $24 \mathrm{~h}$, using $10 \mathrm{mCi}{ }^{14} \mathrm{C}-\mathrm{NaHCO}_{3}$ added to $600 \mathrm{ml}$ of sample. The samples were incubated in on-deck incubators at simulated light levels corresponding to

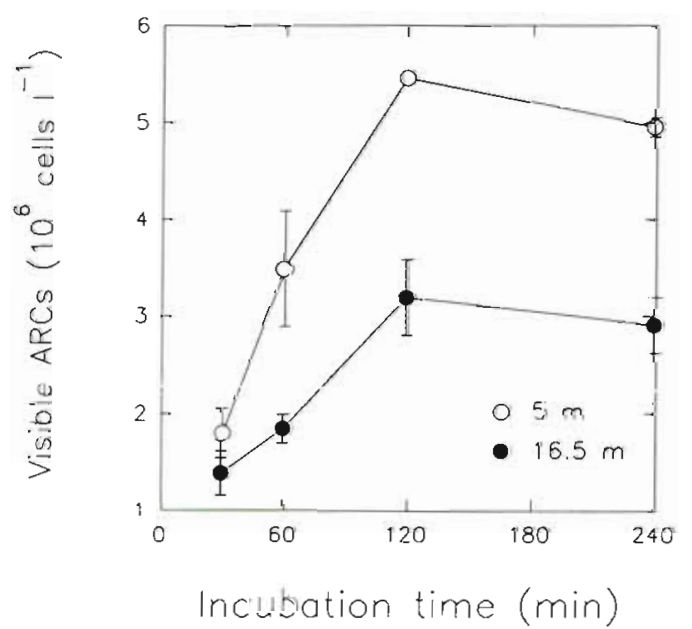

Fig. 2. Effect of increasing incubation time on the number of ARCs visible using epifluorescence microscopy. Samples were from Stn 2 in April 1994, and contained $0.75 \mathrm{mM}$ CTC the depth of collection down to the $0.1 \%$ light level. Activity was counted as with ${ }^{3} \mathrm{H}-\mathrm{TdR}$, and carbon fixation estimated following Parsons et al. (1984).

Samples for nutrient analyses were collected directly from the Niskin bottles using a syringe equipped with a sterile pre-combusted GF/F filter. Samples were analyzed with a Technicon auto-analyzer (Parsons et al. 1984). Ammonia, $\mathrm{NO}_{3}+\mathrm{NO}_{2}$, and $\mathrm{PO}_{4}$ were analyzed immediately on board the ship. Samples for $\mathrm{NO}_{2}$ and $\mathrm{Si}$ were frozen in liquid nitrogen and analyzed 6 to $12 \mathrm{mo}$ later in the laboratory.

All growth rate calculations were done using the simple model where specific growth rate $\mu\left(\mathrm{h}^{-1}\right)=$ $\ln (1+P / B)$, where $P$ is production $h^{-1}$ and $B$ is biomass. Doubling time $(\mathrm{h})$ was calculated as $(\ln 2) / \mu$.

\section{RESULTS}

\section{Experimental verification}

Experiments were conducted twice during a cruise in April 1994. Water used for the 2 experiments (Stns 2 and 4) was taken as the winter ice pack was disintegrating and thermal stratification was very weak. Values for chl $a$ at the surface were low, i.e. 0.68 to $0.73 \mu \mathrm{g}$ $\mathrm{I}^{-1}$ at the 2 stations. Total bacterial numbers were low,

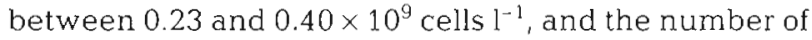
visible ARCs after a $2 \mathrm{~h}$ incubation was between 4.47 and $14.06 \times 10^{6}$ cells $l^{-1}$ in the surface waters.

We examined the effect of the length of the incubation on the number of visible ARCs. This was done to verify that the incubation time was long enough for formazan crystals to accumulate and yield sufficient fluo-

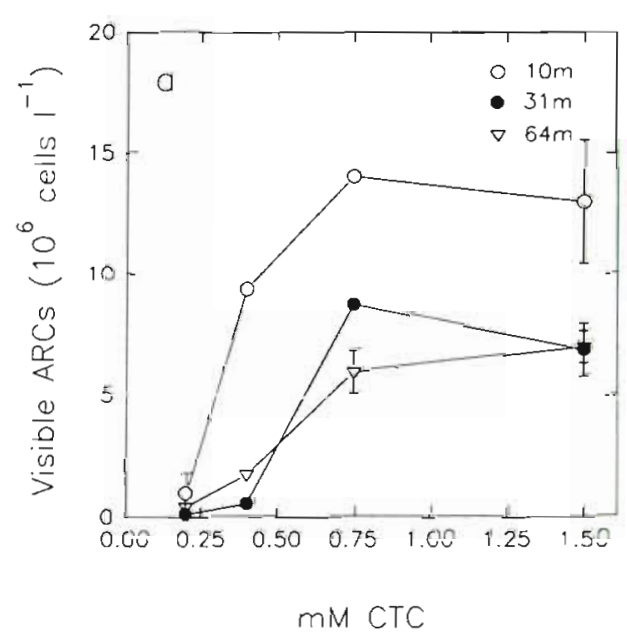

Fig. 3. Effect of increasing CTC concentrations on the number of ARCs visible using epifluorescence microscopy. Samples from 3 depths at Stn 4 in April 1994. All samples were incubated for $2 \mathrm{~h}$ 
rescence to be visible under the microscope. Water from 2 depths was taken from Stn 2. (Fig 1, Fig. 2). The $5 \mathrm{~m}$ sample corresponded to the $50 \%$ irradiance level and the $16.5 \mathrm{~m}$ sample to the $10 \%$ level. The $\sigma_{t}$ data did not show any obvious hydrodynamic separation between the 2 samples (data not shown). The rates of ${ }^{3} \mathrm{H}$-TdR uptake were $1.5 \mathrm{pmol}^{-1} \mathrm{~h}^{-1}$ for the $5 \mathrm{~m}$ sample and $0.4 \mathrm{pmol} \mathrm{l}^{-1} \mathrm{~h}^{-1}$ for the $16.5 \mathrm{~m}$ sample. The 2 depths showed a similar response to the increased incubation time, i.e. the number of visible ARCs was maximum after $2 \mathrm{~h}$ with no further increase at $4 \mathrm{~h}$. The percentage of ARCs was similar in both samples $(1.5 \%$ for the $5 \mathrm{~m}$ sample and $1.4 \%$ for the $16 \mathrm{~m}$ ) whereas there was a difference between depths for the number of bacteria, the total number of ARCs and ${ }^{3} \mathrm{H}$-TdR uptake.

The effect of CTC concentration on the number of visible ARCs was examined using water collected from 3 depths at $\operatorname{Stn} 4$ (Fig. 3). Bacterial numbers were $0.40 \times 10^{9}$, $0.23 \times 10^{9}$, and $0.28 \times 10^{9}$ cells $\mathrm{l}^{-1}$ for the 10,31 and $64 \mathrm{~m}$ samples respectively. Chl a was $0.67 \mathrm{\mu g} \mathrm{l}^{-1}$ for the $10 \mathrm{~m}$ sample and $0.09 \mu \mathrm{g} \mathrm{l}^{-1}$ for the $31 \mathrm{~m}$ sample, no data being available for the $64 \mathrm{~m}$ sample. For all samples the number of ARCs visible after a $2 \mathrm{~h}$ incubation increased as the concentration of CTC went from 0.2 to $0.75 \mathrm{mM}$, but did not show a statistically significant increase between 0.75 and $1.5 \mathrm{mM}$ of CTC [2-way ANOVA followed by multiple comparison tests found significant differences ( $\mathrm{p}<0.001$ ) among depths, and among the 0.2 to $0.75 \mathrm{mM} \mathrm{CTC} \mathrm{levels,} \mathrm{but} \mathrm{no} \mathrm{differ-}$ ence among CTC concentrations between 0.75 and $1.5 \mathrm{mM}$ ]. ARCs accounted for 3.5, 3.8 and $2.1 \%$ of total bacteria in the 10,31 and $64 \mathrm{~m}$ samples, respectively.

\section{Field studies in early winter}

In November and December 1993, a total of 5 series of simultaneous CTC and ${ }^{3} \mathrm{H}-\mathrm{TdR}$ incubations were carried out at 3 stations. Results of all incubations are pooled in Fig. 4. There was no relationship between ${ }^{3} \mathrm{H}$-TdR uptake and bacterial numbers (Fig. $4 \mathrm{a}_{i} \mathrm{r}^{2}=$ $0.01, p>0.05$ ), but the correlation between ${ }^{3} \mathrm{H}$-TdR uptake and CTC-labeled ARCs was significantly different from zero (Fig. $4 \mathrm{~b} ; \mathrm{r}^{2}=$ $0.54, \mathrm{p}<0.001)$. Total numbers of bacteria and ARCs were weakly correlated $\left(\mathrm{r}^{2}=0.11\right.$, $p<0.05$, not shown). ${ }^{3} \mathrm{H}-\mathrm{TdR}$ uptake was well
Correlated with chl a (Fig. $\left.4 c_{;} r^{2}=0.65, p<0.001\right)$ as were ARCs (Fig 4di $\mathrm{r}^{2}=0.78, \mathrm{p}<0.001$ ). Data presented in Fig. 4 include results from 1 complete vertical profile taken at each station. Although each station yielded a slightly different slope, within each station there was a significant correlation between measured ${ }^{3} \mathrm{H}-\mathrm{TdR}$ uptake and total number of ARCs ( $p<0.01$ in all instances).

Stn 1 had the highest $\mathrm{NO}_{3}+\mathrm{NO}_{2}$ and lowest $\mathrm{NH}_{4}$ concentrations in the surface mixed layer (Table 1). In
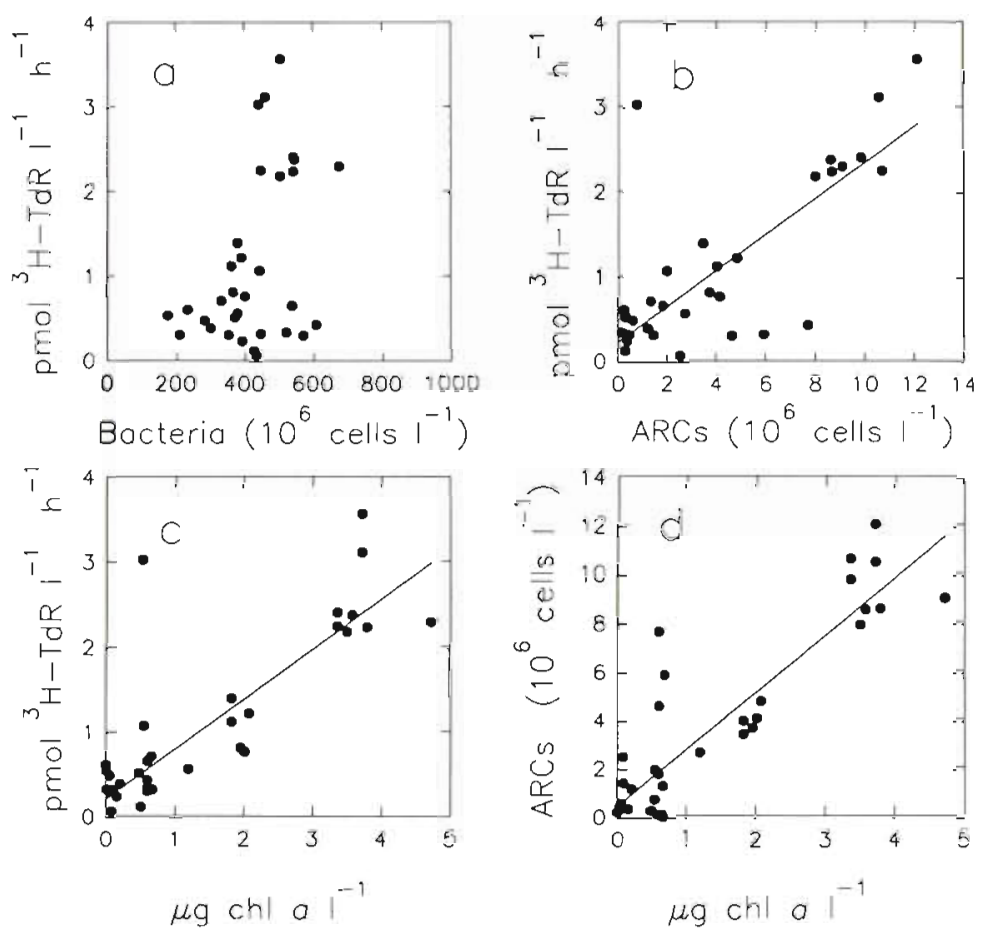

Fig. 4. Summary of December 1993 field data: (a) ${ }^{3} \mathrm{H}-\mathrm{TdR}$ uptake vs total bacteria (no correlation), (b) ${ }^{3} \mathrm{H}-\mathrm{TdR}$ uptake vs ARCs, (c) ${ }^{3} \mathrm{H}-\mathrm{TdR}$ uptake vs chl $a_{1}$ (d) ARCs vs chl a. Lines are Model II linear regressions

Table 1. Comparison of average nutrient concentrations $\left(\mu \mathrm{mol} \mathrm{l}^{-1}\right)$ in the surface mixed layer and below the pycnocline (deep) at the 3 stations sampled in early winter 1993. Values were calculated by dividing the linearly integrated values in the respective zones by depth. There were no deep samples taken on 23 November

\begin{tabular}{|c|c|c|c|c|c|c|c|}
\hline Stn & Date & Zone & $\mathrm{PO}_{4}$ & $\mathrm{NH}_{4}$ & $\mathrm{NO}_{3}+\mathrm{NO}_{2}$ & $\mathrm{NO}_{2}$ & $\mathrm{Si}$ \\
\hline 4 & 23 Nov & $\begin{array}{l}\text { Mixed } \\
\text { Deep }\end{array}$ & $\begin{array}{c}0.71 \\
-\end{array}$ & $\begin{array}{c}1.19 \\
-\end{array}$ & $\begin{array}{l}2.45 \\
-\end{array}$ & $\begin{array}{c}0.15 \\
-\end{array}$ & $\begin{array}{c}3.17 \\
-\end{array}$ \\
\hline 4 & $27 \mathrm{Nov}$ & $\begin{array}{l}\text { Mixed } \\
\text { Deep }\end{array}$ & $\begin{array}{l}0.87 \\
1.26\end{array}$ & $\begin{array}{l}0.81 \\
0.39\end{array}$ & $\begin{array}{r}3.67 \\
11.92\end{array}$ & $\begin{array}{l}0.13 \\
0.09\end{array}$ & $\begin{array}{r}4.91 \\
17.60\end{array}$ \\
\hline 4 & 28 Nov & $\begin{array}{l}\text { Mixed } \\
\text { Deep }\end{array}$ & $\begin{array}{l}0.87 \\
0.87\end{array}$ & $\begin{array}{l}0.97 \\
0.96\end{array}$ & $\begin{array}{l}4.52 \\
4.88\end{array}$ & $\begin{array}{l}0.14 \\
0.14\end{array}$ & $\begin{array}{l}5.42 \\
5.65\end{array}$ \\
\hline 5 & 30 Nov & $\begin{array}{l}\text { Mixed } \\
\text { Deep }\end{array}$ & $\begin{array}{l}0.83 \\
1.31\end{array}$ & $\begin{array}{l}1.23 \\
1.76\end{array}$ & $\begin{array}{l}4.40 \\
9.08\end{array}$ & $\begin{array}{l}0.08 \\
0.09\end{array}$ & $\begin{array}{r}4.34 \\
13.59\end{array}$ \\
\hline 1 & $2 \mathrm{Dec}$ & $\begin{array}{l}\text { Mixed } \\
\text { Deep }\end{array}$ & $\begin{array}{l}1.04 \\
2.00\end{array}$ & $\begin{array}{l}0.43 \\
0.19\end{array}$ & $\begin{array}{l}10.06 \\
17.39\end{array}$ & $\begin{array}{l}0.13 \\
0.11\end{array}$ & $\begin{array}{l}10.57 \\
24.18\end{array}$ \\
\hline
\end{tabular}




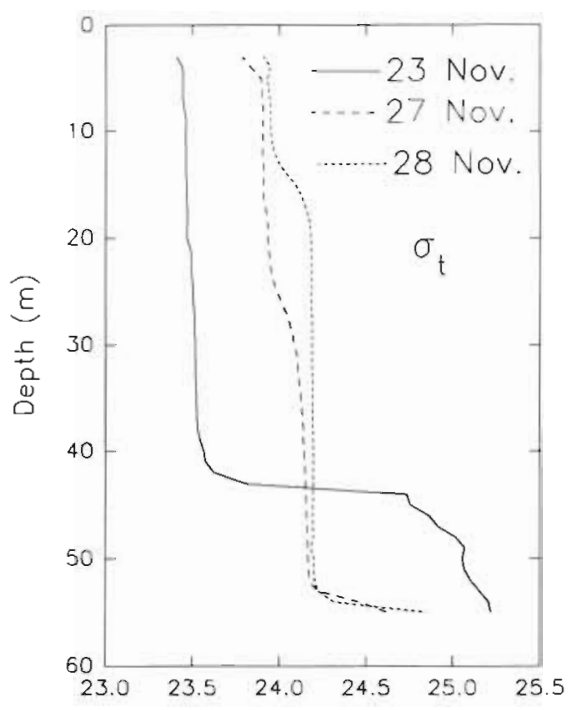

Fig. 5. Vertical o, profiles at Str 4: 23 Nov 1993 08:18 h EST (Eastern Standard Time), 27 Nov 1993 13:32 h EST, 28 Nov 1993 05:18 EST

contrast, Stn 5 had the lower $\mathrm{NO}_{3}+\mathrm{NO}_{2}$ and higher $\mathrm{NH}_{4}$ concentrations. Values at Stn 4 changed over the 3 dates sampled, with nutrients entrained up into the mixed layer from deeper waters as the pycnocline was eroded. Si values were all high except on the first day at $\mathrm{Stn} 4 . \mathrm{PO}_{4}$ was essentially the same in the mixed layer at Stns 4 and 5, and slightly higher at Stn 1. Deeper samples were characterized by higher $\mathrm{NO}_{3}+\mathrm{NO}_{2}, \mathrm{PO}_{4}$ and $\mathrm{Si}$ than in the upper surface mixed layer on all but the last day of sampling at Stn 4 .

Stn 4 was sampled on 3 separate days with different stratification regimes (Fig. 5). Both ${ }^{3} \mathrm{H}-\mathrm{TdR}$ uptake and
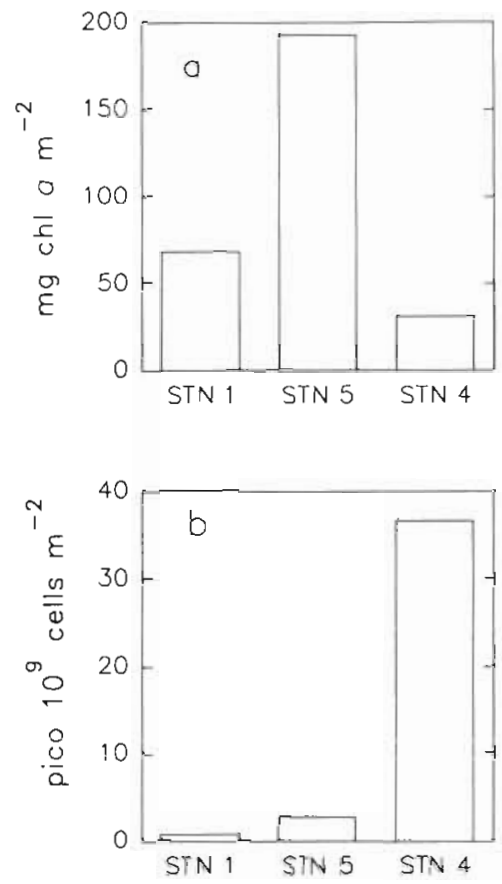

Fig. 6. Comparison of areal concentrations of (a) chl $a$ and (b) picophytoplankton numbers in early winter 1993. All values integrated for the surface mixed layer (ca $50 \mathrm{~m}$ ). Sampling dates: Stn 4, 28 Nov; Stn 5, 29 Nov; Stn 1, 2 Dec

the number of ARCs changed substantially over the 3 sampling dates (Table 2). Stn 4 was also unique in having the highest concentrations of photosynthetic picoplankton, principally Synechococcus sp., in spite of low chl a values (Fig. 6a, b). During the first day at Stn 4 (23 November), the $r^{2}$ values over the 4 sampled depths

Table 2. Stn 4, compilation of results from November 1993, from different depths and days: bacterial production ( ${ }^{3} \mathrm{H}$-TdR uptake); numbers of Actively Respiring Cells (ARCs), bacteria, and picophytoplankton (Pico); primary production (Prim. prod.): chl a. nd: not detectable - - no data

\begin{tabular}{|c|c|c|c|c|c|c|c|}
\hline Date & $\begin{array}{l}\text { Depth } \\
\text { (m) }\end{array}$ & $\begin{array}{c}{ }^{3} \mathrm{H}-\mathrm{TdR} \\
\left(\mathrm{pmol} \mathrm{l} \mathrm{l}^{-1} \mathrm{~h}^{-1}\right)\end{array}$ & $\begin{array}{c}\text { ARCs } \\
\left(10^{6} 1^{-1}\right)\end{array}$ & $\begin{array}{l}\text { Bacteria } \\
\left(10^{6} 1^{-1}\right)\end{array}$ & $\begin{array}{c}\text { Pico } \\
\left(10^{6} d^{-1}\right)\end{array}$ & $\begin{array}{l}\text { Prim prod. } \\
\left(\mu \mathrm{gCl}^{-1} \mathrm{~d}^{-1}\right)\end{array}$ & $\begin{array}{l}\text { Chl a } \\
\left(\mu g ~^{-1}\right)\end{array}$ \\
\hline $23 \mathrm{Nov}$ & 9.5 & 0.44 & 7.71 & 610 & 8.03 & - & 0.60 \\
\hline 23 Nov & 16.0 & 0.32 & 4.65 & 574 & 10.67 & - & 0.60 \\
\hline 23 Nov & 48.0 & 0.08 & 2.53 & 436 & 1.71 & - & 0.08 \\
\hline $23 \mathrm{Nov}$ & 55.0 & 0.33 & 1.46 & 355 & 2.02 & - & 0.10 \\
\hline 27 Nov & 11.5 & 1.08 & 2.02 & 455 & 7.17 & - & 0.55 \\
\hline 27 Nov & 38.0 & 0.67 & 1.83 & 540 & 8.75 & - & 0.60 \\
\hline $27 \mathrm{Nov}$ & 57.0 & 0.25 & 0.38 & 395 & 3.00 & - & 0.16 \\
\hline 28 Nov & 0.0 & 0.36 & 0.14 & 524 & 7.50 & 9.24 & 0.60 \\
\hline $28 \mathrm{Nov}$ & 5.5 & nd & 0.06 & 528 & 7.94 & 6.99 & 0.67 \\
\hline 28 Nov & 11.5 & nd & 0.13 & 824 & 8.13 & 3.83 & 0.65 \\
\hline 28 Nov & 15.0 & nd & 0.16 & 681 & 7.28 & 4.12 & 0.65 \\
\hline $28 \mathrm{Nov}$ & 19.0 & 3.04 & 0.78 & 440 & 7.39 & 3.25 & 0.54 \\
\hline 28 Nov & 38.0 & 0.13 & 0.29 & 429 & 6.91 & 2.00 & 0.51 \\
\hline 28 Nov & 57.0 & 0.53 & 0.31 & 373 & 1.93 & 0.99 & 0.48 \\
\hline
\end{tabular}


Table 3. Summary of stations sampled in early winter 1993, values over the euphotic (Eupho.) zone down to $1 \%$ of surface irradiance. Carbon biomass was estimated using $30 \mathrm{mg} \mathrm{C} \mathrm{mg}^{-1} \mathrm{chl} \mathrm{a} \mathrm{(Phyto.),} \mathrm{and} 10 \mathrm{fg} \mathrm{C} \mathrm{cell}{ }^{-1}$ for bacteria (Bact.) and Actively Respiring cells (ARCs). Doubling times (dt) were calculated as specified in the 'Materials and methods' using a theoretical conversion factor of $2 \times 10^{18}$ cells mol ${ }^{-1}{ }^{3} \mathrm{H}$-TdR incorporated. Phytoplankton population doubling times were corrected for daylength

\begin{tabular}{|c|c|c|c|c|c|c|c|c|c|}
\hline Date & Stn & $\begin{array}{l}\text { Eupho. } \\
\text { depth } \\
\text { (m) }\end{array}$ & 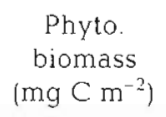 & $\begin{array}{c}\text { Bact. } \\
\text { biomass } \\
\left(\mathrm{mg} \mathrm{C} \mathrm{m}^{-2}\right)\end{array}$ & $\begin{array}{c}\text { ARCs } \\
\text { biomass } \\
\left(\mathrm{mgC} \mathrm{m} \mathrm{m}^{-2}\right)\end{array}$ & $\begin{array}{c}\text { ARCs } \\
\text { bacteria } \\
(\%)\end{array}$ & $\begin{array}{c}\text { Phyto. dt } \\
\text { (h) }\end{array}$ & $\begin{array}{c}\text { ARCs dt } \\
\text { (h) }\end{array}$ & $\begin{array}{c}\text { Bact. dt } \\
\text { (h) }\end{array}$ \\
\hline 23 Nov & 4 & 32 & 608 & 161.6 & 2.28 & 1.24 & - & 6.42 & 686 \\
\hline 27 Nov & 4 & 38 & 533 & 184.2 & 0.74 & 0.40 & - & 1.03 & 178 \\
\hline 28 Nov & 4 & 38 & 657 & 200.8 & 0.14 & 0.07 & 74 & 0.37 & 188 \\
\hline 29 Nov & 5 & 33 & 2322 & 113.2 & 2.49 & 2.20 & 89 & 1.00 & 69 \\
\hline $2 \mathrm{Dec}$ & 1 & 30 & 1575 & 114.8 & 1.09 & 0.95 & 271 & 1.56 & 131 \\
\hline
\end{tabular}

were 0.68 for ARCs versus ${ }^{3} \mathrm{H}-\mathrm{TdR}$ uptake and 0.50 for bacterial numbers versus ${ }^{3} \mathrm{H}-\mathrm{TdR}$ uptake. Two of the samples were taken in the surface mixed layer and two from depths below the pycnocline (Fig. 5). The entire euphotic zone was within the upper mixed layer during this period of stratification (Table 2, Fig. 5). The low chl $a$ and low ${ }^{3} \mathrm{H}$-TdR uptake estimates are consistent with stratification of the water column for some time before sampling (Table 2). While the overall bacterial production was low in the deeper samples, the doubling times for ARCs was $2.7 \mathrm{~h}$ for the $55 \mathrm{~m}$ sample (calculated from data in Table 2) compared to $6.4 \mathrm{~h}$ for populations from the euphotic zone (Table 3).

Four days later (27 November), there had been considerable mixing and surface cooling, and the depth of the surface mixed layer had increased by $10 \mathrm{~m}$ (from 42 to $52 \mathrm{~m}$; Fig. 5). Both ${ }^{3} \mathrm{H}$-TdR uptake and ARCs showed decreasing values with depth, and thus irradiance. The ${ }^{3} \mathrm{H}-\mathrm{TdR}$ uptake rates were better correlated with the number of ARCs than with bacterial numbers. Both ARCs and bacterial production followed the vertical structure of the water column. The next day (28 November), the main pycnocline was at the same depth as on 27 November (Fig. 5). The vertical distribution of chl a was relatively uniform throughout the mixed layer, down to the pycnocline at $52 \mathrm{~m}$ (Table 2 , and in situ fluorescence data not shown). There was evidence of a secondary pycnocline at ca 17 to $18 \mathrm{~m}$, which had developed during the previous $12 \mathrm{~h}$, with the $\sigma_{t}$ values showing slight density differences, and which indicated that either the water mass above was separated from that below or that the water mass was different from that previously sampled. In the upper $15 \mathrm{~m},{ }^{3} \mathrm{H}-\mathrm{TdR}$ uptake rates were low or non-detectable and ARCs were low. The $19 \mathrm{~m}$ sample showed maximum values for both ARCs and ${ }^{3} \mathrm{H}-\mathrm{TdR}$ uptake, and ${ }^{3} \mathrm{H}$-TdR uptake per CTC-labeled cell was the highest measured during the whole study. Bacterial biomass did not change, but the number of ARCs dropped. The number of ARCs (as a percentage of total bacteria at Stn 4) decreased over the sampling period, from 23 November (mean $=0.78 \%, \mathrm{SE}=0.185$ ) to 27 November $($ mean $=0.30 \%, \mathrm{SE}=0.106)$ and 28 November $($ mean $=0.06 \%, \mathrm{SE}=0.022$; see Table 3) A 1-way ANOVA showed these differences to be significant ( $F=$ 14.075, $\mathrm{p}<0.001)$. The deepening of the surface mixed layer (Fig. 5) showed wind-induced mixing and cooling of the water column, which was $4.2^{\circ} \mathrm{C}$ at the surface on 23 November falling to $3^{\circ} \mathrm{C}$ on 27 November down to $2.8^{\circ} \mathrm{C}$ on 28 November.

The water column at Stn 5 (Fig. 7) was deeply mixed with stratification near the bottom. There was no relationship between total numbers of bacteria and ${ }^{3} \mathrm{H}$ -
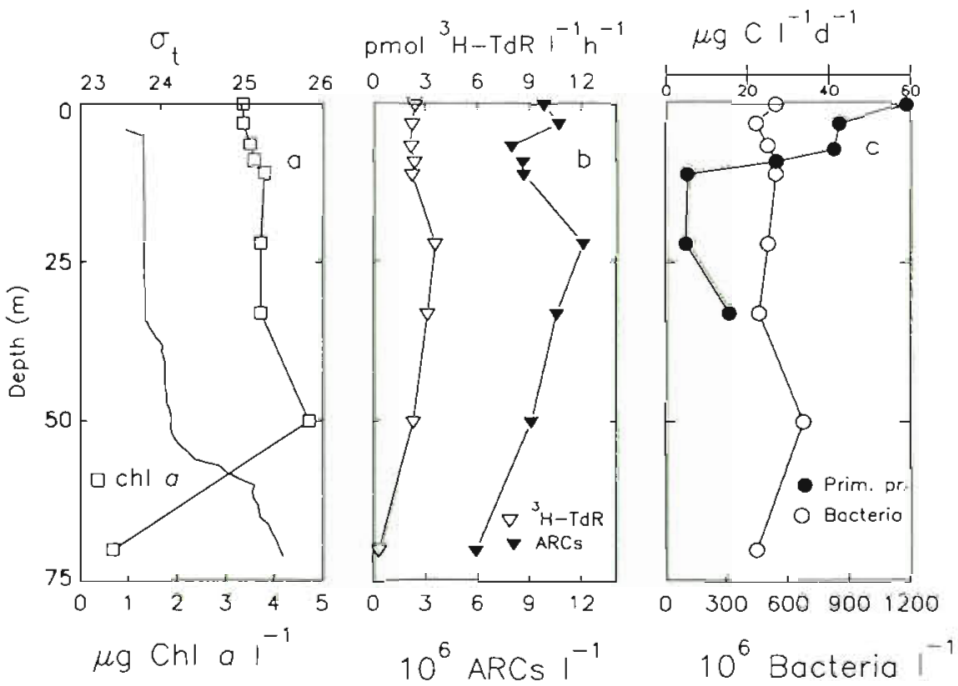

Fig. 7. Stn 5, 29 Nov 1993, showing the depth of the mixed layer in comparison to biological biomass and production measures (top and bottom axes, respectively): (a) $\sigma_{\text {, }}$ and chl $a$, (b) ${ }^{3} \mathrm{H}-\mathrm{TdR}$ and ARCs, (c) primary productivity and total bacteria 
TdR uptake $\left(\mathrm{r}^{2}=0.03, \mathrm{p}>0.05\right)$. ARCs and ${ }^{3} \mathrm{H}-\mathrm{TdR}$ uptake were significantly correlated $\left(r^{2}=0.77, p<\right.$ 0.05). Among all the stations sampled in early winter 1993, Stn 5 had the highest total bacterial productivity

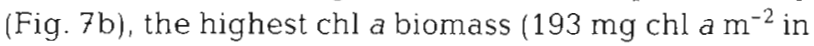
the surface mixed layer; Fig. 6a), and the highest photosynthetic rates $\left(59.3 \mu \mathrm{g} \mathrm{C} \mathrm{l}^{-1} \mathrm{~d}^{-1}\right.$; Fig. $7 \mathrm{c}$, note scale). Values for chl a (Fig. 7a) and total bacteria (Fig. $7 \mathrm{C}$ ) tended to show slight increases down to the bottom of the surface mixed layer. ARCs and ${ }^{3} \mathrm{H}-\mathrm{TdR}$ uptake (Fig. 7b) were maximum higher in the water column. Overall primary productivity in the surface waters was high which translated into a phytoplankton population doubling time in the euphotic zone of $89 \mathrm{~h}$. The theoretical doubling time for the bacteria population $(69 \mathrm{~h})$ in the euphotic zone was 2.7 times that on the last day sampled at $\operatorname{Stn} 4$. The doubling time for ARCs was short (ca 1 h: Table 3).

Stn 1, which was the deepest sampled during the December 1993 cruise (Fig. 8), was characterized by a highly structured water column in terms of temperature (with surface cooling) and density (Fig. 8a). Vertical distributions of chl a (Fig. 8a), ${ }^{3} \mathrm{H}-\mathrm{TdR}$ uptake and ARCs (Fig. 8b), and total bacteria (Fig. 8c) corresponded to the density structure of the water column. The relationship between total bacterial biomass and ${ }^{3} \mathrm{H}-\mathrm{TdR}$ uptake was significant $\left(\mathrm{r}^{2}=0.37, \mathrm{p}<0.05\right)$, but it was not as strong as that between ARCs and ${ }^{3} \mathrm{H}$-TdR bacterial production $\left(r^{2}=0.64, p<0.001\right)$. Photosynthetic activity showed a strong vertical gradient typical of a stratified water column (Fig. 8c).

However, while chl a levels were moderate $(1$ to $2 \mu \mathrm{gg}$ $\left.\mathrm{I}^{-1}\right)$, the overall growth rate of phytoplankton in the
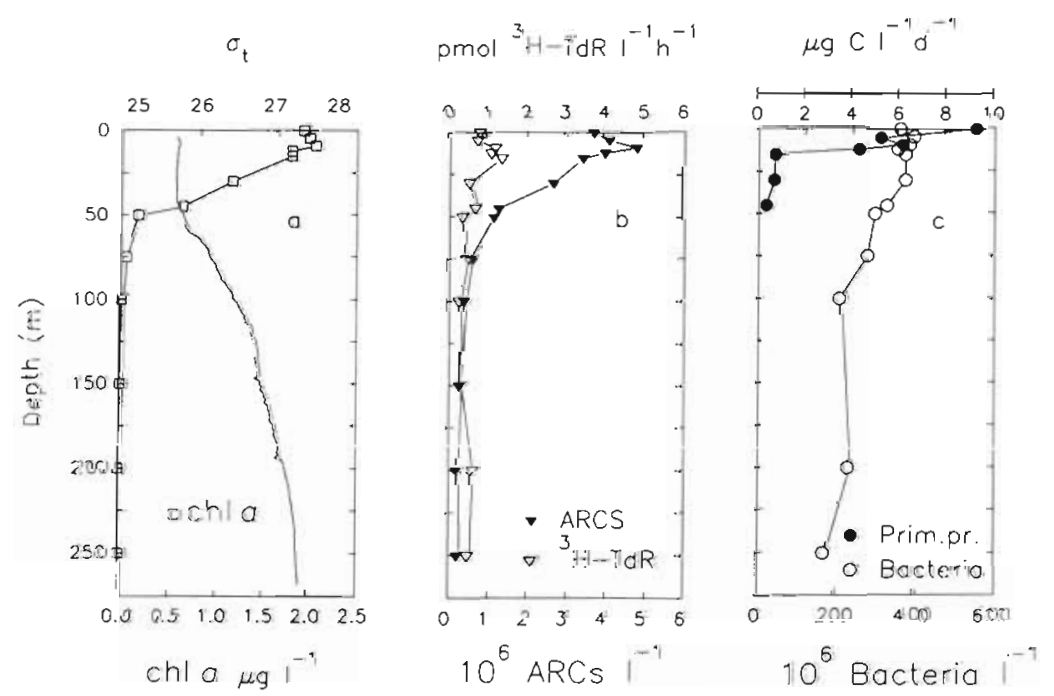

Fig. 8. Stn 1, 2 Dec 1993, showing the depth of the mixed layer and the density structure in comparison to biological biomass and production measures (top and bottom axes, respectively): (a) $\sigma_{\mathrm{t}}$ and $\mathrm{chl} a$, (b) ${ }^{3} \mathrm{H}-\mathrm{TdR}$ and ARCs, (c) primary productivity and total bacteria surface mixed layer was not high, i.e. the average doubling time for the phytoplankton population in the euphotic zone was $271 \mathrm{~h}$ (Table 3). The theoretical doubling time of bacteria using the entire bacterial population would be $131 \mathrm{~h}$, whereas it was 2 orders of magnitude faster for ARCs $(1.56 \mathrm{~h})$. Maximum bacterial activity was located in close proximity to the shallow maximum in photosynthetic productivity.

A comparison of integrated chl $a$, bacterial and ARCs biomass in the euphotic zone at the 3 stations shows that bacterial and photosynthetic biomass were not coupled in these samples (Table 3). Doubling times for phytoplankton and ARCs were longer under stratified (Stn 1 and Stn 4 on 23 November) compared to nonstratified conditions (Stn 5 and Stn 4 on 27 and 28 November, respectively).

\section{DISCUSSION}

\section{Bacterial activity and growth in early winter}

The first set of incubations at $\operatorname{Stn} 4$ did not adhere to the protocol outlined above, which was modified because rough seas forced the ship to leave the station. The incubation was extended to $5.5 \mathrm{~h}$, which may have caused both underestimation of ${ }^{3} \mathrm{H}-\mathrm{TdR}$ bacterial production if ${ }^{3} \mathrm{H}$-TdR uptake was not linear (Robarts \& Zohary 1993) and overestimation of ARCs compared to a $2 \mathrm{~h}$ incubation. However, as stated previously, ${ }^{3} \mathrm{H}$ TdR uptake was always linear up to $6 \mathrm{~h}$ in the Gulf and the experimental results from April showed no increase in ARCs for long incubation times using water with similar chl a values as those at Stn 4 on 23 November (Fig. 3, Table 2). Results were likely a reflection of a true low specific growth rate (based on ARCs) for the populations in the euphotic zone.

Four days later (27 November), the physical structure of the water column, ${ }^{3} \mathrm{H}-\mathrm{TdR}$ uptake characteristics and the percentage of ARCs had changed. On 28 November the situation was not simple. We did not measure significant bacterial activity in the upper mixed layer (down to $15 \mathrm{~m}$ ), which is inconsistent with observations in other environments (cf. Ducklow et al. 1993). Several factors may have been responsible for this, including working near the limits of detection for the ${ }^{3} \mathrm{H}$-TdR technique (Robarts \& Zohary 1993). While the surface productivity per unit chl a measured from samples 
taken at that tirne was similar to that at Stn 5 (Table 3), the community structure at Stn 4 was completely different to that of Stns 5 and 1 (Table 2; Fig. 6). Underneath the upper mixed layer at $19 \mathrm{~m}$, there was comparatively high specific uptake of ${ }^{3} \mathrm{H}-\mathrm{TdR}$ using either ARCs or total bacterial numbers (Table 2). This high, anomalous ${ }^{3} \mathrm{H}-\mathrm{TdR}$ uptake value at $19 \mathrm{~m}$ resulted in the rapid integrated doubling time of ARCs $(<1 \mathrm{~h}$; Table 3 ) in the euphotic zone that day. The closest values to this were those in the deep waters of Stn 1 . It is impossible to say whether the Stn 4 activity at $19 \mathrm{~m}$ was accurate. If it was, it may have been a consequence of increased substrate availability, but without data on DOC availability this was impossible to confirm. Alternatively, physical conditions may have been sufficient for the creation of an enzymatically distinct community, which enables use of specific organic molecules present in the immediate surroundings, over the time and spatial scales considered (cf. Hoppe et al. 1988, Chróst \& Rai 1993 and references therein).

Stn 5, while not strongly stratified at the time of sampling, retained a deep surface mixed layer (Fig. 7). High chl $a$, primary productivity and nutrients suggest that the bloom was in progress, sustained by recent erosion of the pycnocline. The highest bacterial activity was situated just below the zone of primary productivity (Fig. 7), following a pattern which has been described for spring blooms (Ducklow et al. 1993 , Kirchman et al. 1993).

Stn 1 had the most stable water column sampled during this period (Fig. 8 vs Figs. 5a \& 7a). The close coupling between primary production, bacterial production, bacterial concentrations and chl a is typical of many temperate marine systems during periods of stratification (Banse 1992, Ducklow et al 1992). Although nutrient levels remained high (Table 1), other factors such as light or temperature seem to have limited productivity compared to Stn 5 (Fig. 7).

The $\operatorname{Stn} 1 \sigma_{t}$ profile was typical of the Northwestern Gulf, where this structure is retained throughout winter (Bugden 1991). Bacterial populations in the deep waters (Fig. 8) had presumably been trapped there for some time. The deep populations at Stn 1 were characterized by both low productivity in terms of ${ }^{3} \mathrm{H}-\mathrm{TdR}$ uptake and low numbers of ARCs. Specific growth rate (calculated from Fig. 8) for ARCs was $\mu=0.7$ to 1.7 . which corresponds to doubling times of 1 h or less. These doubling time were in contrast to those of the euphotic zone, which were close to 2 h (Table 3). However, since the deep samples were incubated for only $2 \mathrm{~h}$, we cannot rule out the possibility that the number of ARCs was underestimated. Grossmann (1994) found a high percentage of bacteria evidently active in deep samples from the Weddell Sea using ${ }^{3} \mathrm{H}-\mathrm{TdR}$ track microautoradiography to test activity, but only after a
$16 \mathrm{~h}$ incubation. The rapid doubling times should be interpreted with caution given the limits of both ${ }^{3} \mathrm{H}$ TdR-methodology and the ARCs assay.

In general the relationship between bacterial numbers and bacterial production changed with changing mixing regime, supporting our original hypothesis of a decoupling between these 2 factors at this time of year. The total number of active bacteria was low throughout this period and showed much higher variation among stations and depths than total bacterial numbers.

\section{Ecological interpretation of the CTC assay}

Severin et al. (1985) described CTC as a measure of redox activity in cells. The tetrazolium salt reduction occurs via membrane-bound redox enzymes and is visible on the surface of cells. Subsequent work showed that the redox activity is probably related to a cell membrane-bound NAD(P)H-oxidase system (Stellmach \& Severin 1987). Free-living bacteria have a variety of respiratory chains, with a multiplicity of terminal oxidases in contrast to the single cytochrome-c oxidase of mitochondria. However, in most systems examined, cytoplasmic NAD $(\mathrm{P}) \mathrm{H}$ is usually the supplier of reducing power and dehydrogenases are thought to be ubiquitous (Sone 1990, Garcia-Horsman et al, 1994). The reduction of tetrazolium salts, including CTC, in intact living cells is thought to be mediated by dehydrogenases along with the membrane bound NAD(P)H-oxidase system (Van Noorden \& Tas 1982, Van Noorden et al. 1985, Stellmach \& Severin 1987, Severin \& Seidler 1992).

Although the above argument provides a basis to accept that CTC is a good redox marker, this is not proven for all bacteria which may live in the sea. Nevertheless, the present study showed that the number of ARCs as measured by CTC (and epifluorescence microscopy) varied in an ecologically interpretable manner and correlated well with TdR-based production estimates. The results indicate that the CTC assay is promising but requires further research to understand its exact interpretation.

The fluorescent water-insoluble formazan crystals tend to remain visible and in close association with the cell surface after being reduced by a membrane-bound redox system (Severin et al. 1985). The assay as used here was for tracking a particular portion of the total bacteria population and not for measuring respiration (Kaprelyants \& Kell 1993a, b). In order to quantify respiratory activity, a dissolution step is required, whose resulting product is not fluorescent so that CTC has no advantage over other tetrazolium salts. Since the assay does not involve substrate uptake kinetics or an enzy- 
matic saturation, the concentration of CTC and time required to adequately detect respiring cells is not the same as that to measure maximum respiration. The selection of incubation time and CTC concentration was dictated by the fact that bacterial growth characteristics change rapidly once samples are taken from the sea and placed into bottles (Ammerman et al. 1984, Ducklow et al. 1992) and that CTC is probably toxic at high concentrations (Rodriguez et al. 1992). The very low percentage of ARCs measured in early winter suggested further experiments to verify our incubation time and CTC concentrations. Results shown in Figs. 2 $\& 3$ indicate that our original protocol was reasonable for the low bacterial concentrations found in these natural waters. However, we do not suggest that this protocol would be optimal under other conditions.

We found that the number of bacteria able to reduce CTC to a formazan salt in sufficient quantities to be visible (ARCs) was a better predictor of bacterial production as measured by ${ }^{3} \mathrm{H}-\mathrm{TdR}$ than total bacterial numbers during a hydrodynamically unstable time of year. To apply the CTC assay to the field, a number of important departures from the study by Rodriguez et al. (1992) were necessary: (1) CTC was at a low final concentration $(0.75 \mathrm{mM})$ for reasons discussed above. (2) All work was done under conditions which prevented the CTC-containing samples from being exposed to light levels which may have photoreduced the tetrazolium salt. (3) No additional substrate which would confound interpretation of actual ARCs was added. (4) Samples were incubated near in situ temperature conditions. (5) As mentioned in the 'Introduction', co-staining with DAPI interferes with both DAPI and ARCs determination, so it was not done. (6) A water-miscible mounting medium was used which prevents dissolution of formazan crystals. (7) Samples were mounted on $0.2 \mu \mathrm{m}$ Anodisc filters, which facilitates the use of the mounting medium required. These filters also stay flat and result in more filter area being accessible to examination. (8) Samples were examined with a filter block which completely eliminated the risk of exposure to light at wavelengths in the UV or violet range. A simple experiment was done by putting CTC in distilled water on a microscope slide, and examining this using a fluorescence excitation source of 400 to $450 \mathrm{~nm}$. The result was spontaneous and rapid formation of crystals. This means both the excitation wavelengths and cutoff band of the block are critical. (9) The sample slides were stored in the dark and in a freezer. This ensures that fluorescence in the sample was neither increased due to photoreduction nor lost due to excitation by ambient light. Storage in the freezer also decreases the possibility of micro-biological change on the slide due to imperfect preservation that may occur with filtered samples. (10) In addition to the above, a protocol which distinguishes ARCs from photosynthetic picoplankton was described in the 'Materials and methods'. This is necessary for samples from most aquatic natural environments

\section{Bacterial activity in marine waters}

Assuming that the number of ARCs provides an approximate measure of metabolically active cells, it appears that 97 to $99 \%$ (Fig. 5, Table 3) of the bacteria counted using standard fluorescent techniques were not participating in carbon and nutrient transfer or recycling in the pelagic zone of the Gulf of St. Lawrence during early winter. There has been wide speculation on the control and limils of growth for bacteria in the sea (recently reviewed by Kjelleberg et al. 1993). Reasons put forward to explain in situ productivity and biomass of marine bacteria include substrate limitation (cf. Kjelleberg et al. 1993), the impact of protozoan grazers (cf. Fuhrman 1992 and references therein) and viral infection (cf. Børsheim 1993). The small and variable proportion of CTC-positive bacteria found in the present study, as well as other studies (Meyer-Reil 1978, Tabor \& Neihof 1984, del Giorgio \& Scarborough 1995), may explain reports of low apparent specific growth rates in the sea. Bacterial generation times have been calculated to be $1 \mathrm{wk}$ or more in oligotrophic marine environments (Fuhrman et al. 1989), compared with laboratory studies in which doubling times range from minutes to hours (e.g. Pickett 1982). The evidence presented here suggests that this disparity may simply reflect the very small proportion of the population which is actually actively growing at sea at any given time. This is not surprising given the ability of bacteria to survive starvation (Morita 1993) and the diversity of both species (Giovannoni et al. 1990, Lee \& Fuhrman 1991) and available substrates (Azam et al. 1993) in marine waters.

Our ARCs analysis suggests that the high concentrations of total bacteria found in upper oceanic waters, including those sampled in the present study, are not a function of bacterial growth but more likely reflect inefficient loss processes. In the Gulf during early winter: metabolically active cells accounted for a low and variable percentage of the total population. Sinking rates for such small cells are very slow (Stokes' law) so that sedimentation losses are minimal. Shimeta (1993) proposed an encounter rate model for small predators and prey. Results of the model were consistent with those of Rubenstein \& Koehl (1977), who suggested that bacteria-sized particles fall within a minimum encounter rate window. Other researchers have also noted that there is a threshold prey concentration for bacterial grazers (ca $10^{5} \mathrm{ml}^{-1}$; Nakano 1994) and for 
viruses (ca $5 \times 10^{5} \mathrm{ml}^{-1}$; Steward et al. 1992). The early winter bacterial populations recorded during the present study were close to that minimum. If active individual bacteria have the same probability of being grazed by protozoa or encountered by viruses as any other individual in the bacterial population, there would be strong selection pressure against cells with low activity or division rates, so that their losses would be much greater than growth. This would eventually leave only active bacteria. However, if the actively growing cells are selectively grazed (cf. Van Houten 1988), this sub-population would be cropped down to the grazing threshold mentioned above, leaving only a refugee population, which, in compensation for high loss rates, would require high specific growth rates. This is consistent with what we observed in the present study. In deep waters, viruses may play the same role as protozoa and flagellates near the surface, that is, causing selective loss of active bacteria. Jürgens \& Güde (1994) have recently suggested that there may be a fraction of the bacteria which exhibit high growth, high losses, and high turnover. They used the analogy of turnover in the DOC pool, with a large refractory part and a small labile part which turns over rapidly. The changing percentage of active bacteria for different aquatic systems and seasons (Hoppe 1976, Kogure et al. 1980, Tabor \& Neihof 1984, del Giorgio \& Scarborough 1995) and changing specific growth rates under different conditions (e.g. surface vs deeper waters) support this view.

Kristiansen et al. (1992) suggested, using chemostat data, that the overall growth efficiency of aquatic bacteria is influenced by their generation time. Table 3 shows that the theoretical generation time of the average bacteria changes depending on what was used as the base population, which in turn has major implications on the estimation of carbon fluxes. In summary, the total number of bacteria may be controlled by loss processes, and future studies in bacterial productivity need to be focused on controls of metabolic activity that result in growth and turnover of the active bacterial pool. Assessing the utility of CTC for quantifying the absolute numbers of ARCs will require more measurements over a wider range of conditions than those covered in the present study. Further studies which elucidate the mechanisms of CTC reduction in a wide variety of bacteria are also needed. The CTC-formazan technique for measuring ARCs presented here was rapid, sensitive and was used in rough seas, requiring a minimum of shipboard laboratory space. The analysis of ARCs in conjunction with the more established measures of bacterial dynamics provides another perspective on bacterial biomass in aquatic systems.

The CTC assay confirms a number of previous observations that have been made using ${ }^{3} \mathrm{H}-\mathrm{TdR}$ and
${ }^{14} \mathrm{C}$ or ${ }^{3} \mathrm{H}$-leucine, notably that bacterial activity tends to be associated with chl a biomass and photosynthetic activity. Bacterial biomass and production are strongly correlated with chl a concentrations in a number of aquatic systems (Cole et al. 1988, Simon et al. 1992). This relationship was strong in samples from vertically stratified conditions. However, as frequently found within systems bacteria and chl a are often uncoupled (cf. Shiah \& Ducklow 1994). In this study, while the water column was being mixed, chl a and bacteria numbers remained coupled, but bacterial production was no longer closely correlated to either bacteria numbers or chl a. An important result of the present study is that the number of ARCs remained correlated to bacterial production rates regardless of mixing conditions whereas total numbers of bacteria did not.

Acknowledgements. This work was undertaken as part of the JGOFS Canada Programme. Financial support was provided by the Natural Sciences and Engineering Research Council (NSERC) of Canada, the Department of Fisheries and Oceans (DFO) Canada and by grants to GIROQ from NSERC and funds from FCAR of Québec. This is a contribution to the programmes of GIROQ (Groupe interuniversitaire de recherches océanographiques du Québec) and the Maurice-Lamontagne Institute (DFO). We thank the Officers and Crew of the CSS 'Parizeau' (Bedford Institute of Oceanography) and the 'Sir Wilfrid Laurier' (Canadian Coast Guard). In addition we are indebted to Alain Gagné and Marie-Lyne Dubé for assistance in the laboratory and field, as well as L. Guy Millette, and Joel Wesson for physical data analyses. Sincere thanks to several anonymous reviewers and W. F. Vincent, Université Laval, for valuable discussions and encouragement to C.L.

\section{LITERATURE CITED}

Ammerman JW, Fuhrman JA, Hagström $\AA$, Azam F (1984) Bacterioplankton growth in seawater I. Growth kinetics and cellular characteristic in seawater cultures. Mar Ecol Prog Ser 18:31-39

Azam F, Smith DC, Carlucci AF (1992) Bacterial transformations and transport of organic matter in the Southern California Bight. Prog Oceanogr 30:151-166

Azam F, Smith DC, Steward GF, Hagström $\AA$ (1993) Bacteriaorganic matter coupling and its significance for oceanic carbon cycling. Microb Ecol 28:167-179

Banse K (1992) Grazing, temporal changes of phytoplankton concentrations, and the microbial loop in the open sea In: Falkowski PG, Woodhead AD (eds) Primary productivity and biogeochemical cycles in the sea. Plenum Press, New York, p 409-441

Børsheim KY (1993) Native marine bacteriophages. FEMS Microbiol Ecol 102:141-159

Bugden GL (1991) Changes in the temperature-salinity characteristics of the deeper waters of the Gulf of St. Lawrence over the past several decades. In: Therriault JC (ed) The Gulf of St. Lawrence: small ocean or big estuary? Can Spec Publ Fish Aquat Sci 113:139-147

Byrd JJ, Colwell RR (1993) Microscopy applications for analysis of environmental samples. In: Levin MA, Seidler RJ, Rogu M (eds) Microbial ecology, principles, methods, and applications. McGraw-Hill Inc, New York, p 93-112 
Chróst RJ, Raj H (1993) Ectoenzyme activity and bacterial secondary production in nutrient-improverished and nutrient-enriched freshwater mesocosms. Microb Ecol 23: $131-150$

Cole JJ, Findlay S, Pace ML (1988) Bacterial production in fresh and saltwater ecosystems, a cross-system overview. Mar Ecol Prog Ser 43:1-10

del Giorgio PA, Scarborough G (1995) Increase in the proportion of metabolically active bacteria along gradients of enrichment in freshwater and marine plankton: implications on estimates of bacterial growth and production rates. J Plankton Res 17:1905-1924

Ducklow HW, Kirchman DL (1983) Bacterial dynamics and distribution during a spring diatom bloom in the Hudson River Plume, U.S.A. J Plankton Res 5:333-355

Ducklow HW, Kirchman DL, Quinby HL (1992) Bacterioplankton cell growth and macromolecular synthesis in seawater cultures during the North Atlantic spring phytoplankton bloom, May, 1989. Microb Ecol 24:125-144

Ducklow HW, Kirchman DL, Quinby HL, Carlson CA, Dam HG (1993) Stocks and dynamics of bacterioplankton carbon during the spring bloom in the eastern North Atlantic Ocean. Deep Sea Res 40:245-263

Fuhrman JA (1992) Bacterioplankton roles in cycling of organic matter. In: Falkowski PG, Woodhead AD (eds) Primary productivity and biogeochemical cycles in the sea. Plenum Press New York, p 361-383

Fuhrman JA, Azam F (1980) Bacterioplankton secondary production estimates for coastal waters of British Columbia, Antarctica, and California. Appl Environ Microbiol 39: $1085-1095$

Fuhrman JA, Sleeter TD, Carlson CA, Proctor LM (1989) Dominance of bacterial biomass in the Sargasso Sea and its ecological implication. Mar Ecol Prog Ser 57:207-217

Garcia-Horsman JA, Barquera B, Rumbley J, Jixiang M, Gennis RB (1994) The superfamily of heme-copper respiratory oxidases. J Bacteriol 176:5587-5600

Giovannoni SJ, Britschgi TB, Moyer CL, Field KG (1990) Genetic diversity in Sargasso Sea bacterioplankton. Nature 345:61-63

Grossmann S (1994) Bacterial activity in sea ice and open water of the Weddell Sea, Antarctica: a microautoradiographic study. Microb Ecol 28:1=1.8

Hobbie JE, Daley RJ, Jasper S (1977) Use of nuclepore filters for counting bactena by fluorescence microscopy. Appl Environ Microbiol 33:1225-1228

Holm-Hansen O, Lorenzen CJ. Holmes RW, Strickland JD (1965) Fluorometric determination of chlorophyll. J Cons Int Explor Mer 30:3-15

Hoppe HG (1976) Determination and properties of actively metabolizing heterotrophic bacteria in the sea, investigated by means of micro-autoradiography. Mar Biol 36: 291-302

Hoppe HG, Kim SJ, Gocke K (1988) Microbial decomposition

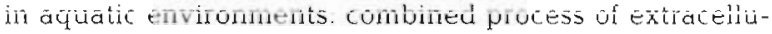
lar enzyme activity and substrate uptake. Appl Environ Microbiol 54:784-790

Jurgens K, Güde H (1994) The potential importance of grazing-resistant bacteria in planktonic systems. Mar Ecol Prog Ser 112:169-188

Kaprelyants AS, Kell DB (1993a) The use of 5-cyano-2,3, ditolyl tetrazolium chloride and flow cytometry for the visualization of respiratory activity in individual cells of Micrococcus luteus.J Microb Meth 17:115-122

Kaprelyants AS, Kell DB (1993b) Dormancy in stationaryphase cultures of Micrococcus luteus: flow cytometric analysis of starvation and resuscitation. Appl Environ
Microbiol 59:3187-3196

King LA, Parker BC (1988) A simple, rapid method for enumerating total viable and metabolically active bacteria in groundwater. Appl Environ Microbiol 54:1630-1631

Kirchman DL, Keil RG, Simon M. Welschmeyer NA (1993) Biomass and production of heterotrophic bacterioplankton in the oceanic subarctic Pacific. Deep Sea Res 40:967-988

Kjelleberg S, Flärdh KBG, Nyström T, Moriarty DJW (1993) Growth limitation and starvation of bacteria. In: Ford TE (ed) Aquatic microbiology: an ecological approach. Blackwell Scientific Publications, New York, p 289-320

Kogure K, Simidu U, Taga N (1980) Distribution of viable marine bacteria in neritic seawater around Japan. Can J Microbiol 26:318-323

Kristiansen K, Nielsen H, Riemann B, Fuhrman JA (1992) Growth efficiencies of freshwater bacterioplankton. Microb Ecol 24:145-160

Lee SH, Fuhrman JA (1991) Spatial and temporal variation of natural bacterioplankton assemblages studied by total genomic DNA cross-hybridization. Limnol Oceanogr 36: $1277-1287$

Martin-Jézéquel V, Videau C (1.992) Phytoplankton and bacteria over the transient area of the continental slope of the Celtic Sea in spring. I. Vertical distribution and productivity. Mar Ecol Prog Ser 85:289-301

McFeters GA, Yu FP, Pyle BH, Stewart PS (1995) Physiological assessment of bacteria using fluorochromes. J Microbiol Meth 21:1-13

Meyer-Reil LA (1978) Autoradiography and epifluorescence microscopy combined for the determination of number and spectrum of actively metabolizing bacteria in natural waters. Appl Environ Microbiol 36:506-512

Moore RP (ed) (1985) Handbook on tetrazolium testing. International Seed Testing Association, Zürich

Morita RY (1993) Bioavalability of energy and the starvation state. In: Kjelleberg $S$ (ed) Starvation in bacteria. Plenum Press, New York, p 1-23

Nakano S-I, (1994) Carbon:nitrogen:phosphorus ratios and nutrient regeneration of a heterotrophic flagellate fed on bacteria with different elemental ratios. Arch Hydrobiol 129:257-271

Parsons TR, Maita Y, Lalli CM (1984) A manual of chemical and biological methods for seawater analysis. Pergamon, Oxford

Pickett AM (1982) Growth in a changing environment. In: Bazin MJ (ed) Microbial population dynamics. CRC Series in Mathematical Models in Microbiology. CRC Press Inc, Boca Raton, p 91-124

Porter KG, Feig YS (1980) The use of DAPI for identifying and counting aquatic microflora. Limnol Oceanogr 25:943-948

Robarts RD, Zohary $T$ (1993) Fact or fiction - bacterial growth rates and production as determined by [methyl${ }^{3} \mathrm{H}$ | thymidine? Adv Microb Ecol 13:371-425

Rodriguez GG, Ishiguro DP, Ridgway HF (1992) Use of a fluorescent redur piótue fó direct visualizátioñ of actively respiring bacterla. Appl Environ Microbiol 58:1801-1808

Rubenstein DI, Koehl MAR (1.977) The mechanisms of filter feeding: some theoretical considerations. Am Nat 111. $981-994$

Severin E Seidler E (1992) Calıbration of a flow cytometric assay of glucose-6-phosphate dehydrogenase activity. Cytometry 13:322-326

Severin E, Stellmach J, Nachtigal H-H (1985) Fluorimetrıc assay of redox activity in cells. Analytica Chım Acta 170: $341-346$

Shiah FK, Ducklow HW (1994) Temperature regulation of heterotrophic bacterioplankton abundance, production, and 
specific growth rate in Chesapeake Bay. Limnol Oceanogr $39: 1243-1258$

Shimeta J (1993) Diffusional encounter of submicrometer particles and small cells by suspension feeders. Limnol Oceanogr 38:456-465

Simon M, Cho BC. Azam F (1992) Significance of bacterial biomass in lakes and the ocean. Mar Ecol Prog Ser 86 $103-110$

Simon M, Tilzer MM (1987) Bacterial response to seasonal changes in primary production and phytoplankton biomass in Lake Constance. J Plarkton Res 9:535-552

Sone N (1990) Respiration-driven proton pumps. In: Krulwich TA (ed) Bacterial energetics. Academic Press, New York, p $1-32$

Stellmach J (1984) Fluorescent redox dyes 1. Production of fluorescent formazan by unstimulated and phorbol esteror digitonin-stimulated Ehrlich ascites tumor cells. Histochemistry 80:137-143

Stellmach J, Severin E (1987) A fluorescent redox dye. Influence of several substrates and electron carriers on the tetrazolium salt-formazan reaction of Ehrlich ascites tumor cells. Histochem J 19:21-26

Steward GF, Wikner J, Smith DC, Cochlan WP, Azam F (1992)

Responsible Subject Editor: J. T. Hollibaugh, Tiburon, California, USA
Estimation of virus production in the sea: I. Method development. Mar Microb Food Webs 6:57-78

Tabor PS, Neihof RA (1984) Direct determination of activities for microorganisms of Chesapeake Bay populations. Appl Environ Microbiol 48:1012-1019

Therriault JC (ed) (1991) The Gulf of St. Lawrence: small ocean or big estuary? Can Spec Publ Fish Aquat Sci 113

Turley CM, Hughes DJ (1992) Effects of storage on direct estimates of bacterial numbers of preserved seawater samples. Deep Sea Res 39:375-394

Van Houten J (1988) Chemoresponse mechanisms: toward the molecular level. J Protozool 35:241-243

Van Noorden CJF, Kooij A, Vogels IMC. Frederiks WM (1985) On the nature of the 'nothing dehydrogenase' reaction. Histochem J 17:1111-1118

Van Noorden CJF, Tas J (1982) The role of exogenous electron carriers in NAD(P)-dependent dehydrogenase cytochemistry studied in vitro and with a model system of polyacrylamide films. J Histochem Cytochem 30:12-20

Zimmermann R, Iturriaga R, Becker-Birck J (1978) Simultaneous determination of the total number of aquatic bacteria and the number thereof involved in respiration. Appl Environ Microbiol 36:926-935

Manuscript first received: June 10,1995

Revised version accepted: December 28, 1995 